\title{
Isolation of Ribosomal Particles from the Unicellular Cyanobacterium Synechocystis sp. PCC 6803
}

Carla V. Galmozzi ${ }^{1,2}$ and M. Isabel Muro-Pastor ${ }^{1, *}$

\author{
${ }^{1}$ Instituto de Bioquímica Vegetal y Fotosíntesis, CSIC-Universidad de Sevilla, Sevilla, Spain; ${ }^{2} Z e n t r u m$ \\ für Molekulare Biologie der Universität Heidelberg, Heidelberg, Germany \\ *For correspondence: imuro@ibvf.csic.es
}

\begin{abstract}
[Abstract] Isolation of ribosomal particles is an essential step in the study of ribosomal components as well as in the analysis of trans-acting factors that interact with the ribosome to regulate protein synthesis and modulate the expression profile of the cell in response to different environmental conditions. In this protocol, we describe a procedure for the isolation of $70 \mathrm{~S}$ ribosomes from the unicellular cyanobacterium Synechocystis sp. PCC 6803 (hereafter Synechocystis). We have successfully used this protocol in our study of the cyanobacterial ribosomal-associated protein LrtA, which is a homologue of bacterial HPF (hibernation promoting factor) (Galmozzi et al., 2016).
\end{abstract}

Keywords: Ribosome, Sucrose gradients, Synechocystis, Cyanobacteria, Photosynthetic prokaryotes

[Background] Few biochemical studies have been reported for cyanobacterial ribosomes. Anabaena variabilis strain M3 (PCC 7118, ATCC 27892) 70S ribosomal particles have been isolated by differential centrifugation and then, ribosomal proteins were analysed by two-dimensional electrophoresis (Sato et al., 1998). Ribosomes have also been prepared from Synechococcus sp. PCC 6301 cells using a protocol combining differential centrifugation and sucrose step gradients (Sugita et al., 2000). Fractionation of cell extracts by differential centrifugation has also been employed in the preparation of ribosomal samples for the development of an in vitro translation system in different Synechococcus strains (Mutsuda and Sugiura, 2006). The method described here for Synechocystis, based on the one described for Synechococcus (Sugita et al., 2000), allows purification of ribosomal particles using ultracentrifugation of linear sucrose gradients.

\section{Materials and Reagents}

1. Centrifuge tubes, polypropylene $15 \mathrm{ml}$ (Beckman Coulter, catalog number: 342082)

2. $1.5 \mathrm{ml}$ microcentrifuge tubes (Microtubes) (Corning, Axygen $^{\circledR}$, catalog number: MCT-150-C)

3. $1.5 \mathrm{ml}$ polystyrene spectrophotometer cuvettes (KARTELL SPA CIA DELLE INDUSTRIE, catalog number: 1938)

4. Ultracentrifuge thin-wall polyallomer tubes $13.2 \mathrm{ml}$ (Beckman Coulter, catalog number: 331372)

5. $0.45 \mu \mathrm{m}$ Millipore filter (MILLEX-HV PVDF) (EMD Millipore, catalog number: SLHV033RS)

6. Alumina type A-5 (Sigma-Aldrich, catalog number: A2039)

Note: This product has been discontinued. 
7. Micropipette tips $(200 \mu \mathrm{l})$ (Daslab, catalog number: $162001 \mathrm{X})$

8. Micropipette tips (1,000 $\mu \mathrm{l})$ (Daslab, catalog number: 162222X)

9. Silicone tubing (VWR, catalog number: 228-0713)

10. Synechocystis sp. PCC 6803 cells (Pasteur Culture Collection of Cyanobacteria)

11. Milli-Q water

12. Distilled water

13. Sodium nitrate $\left(\mathrm{NaNO}_{3}\right)$ (AppliChem, catalog number: 141702)

14. Sodium bicarbonate $\left(\mathrm{NaHCO}_{3}\right)$ (AppliChem, catalog number: 141638)

15. Potassium phosphate dibasic $\left(\mathrm{K}_{2} \mathrm{HPO}_{4}\right)$ (AppliChem, catalog number: 141512)

16. Magnesium sulfate heptahydrate $\left(\mathrm{MgSO}_{4} \cdot 7 \mathrm{H}_{2} \mathrm{O}\right)$ (Duchefa Biochemie, catalog number: $\mathrm{M0513}$ )

17. Citric acid monohydrate $\left(\mathrm{C}_{6} \mathrm{H}_{8} \mathrm{O}_{7} \cdot \mathrm{H}_{2} \mathrm{O}\right)$ (EMD Millipore, catalog number: 100244)

18. EDTA-Na2 (Duchefa Biochemie, catalog number: E0511)

19. Calcium chloride dihydrate $\left(\mathrm{CaCl}_{2} \cdot 2 \mathrm{H}_{2} \mathrm{O}\right)$ (Merck, catalog number: 2382)

20. Citrate $\mathrm{Fe}_{-} \mathrm{NH}_{4}$ (Sigma-Aldrich, catalog number: F5879)

21. Sodium phosphate $\left(\mathrm{Na}_{2} \mathrm{CO}_{3}\right)$ (Merck, catalog number: 6392)

22. Boric acid $\left(\mathrm{H}_{3} \mathrm{BO}_{3}\right)$ (EMD Millipore, catalog number: 100165)

23. Manganese(II) chloride tetrahydrate $\left(\mathrm{MnCl}_{2} \cdot 4 \mathrm{H}_{2} \mathrm{O}\right)$ (EMD Millipore, catalog number: 1059270)

24. Sodium molybdate dehydrate $\left(\mathrm{Na}_{2} \mathrm{MoO}_{4} \cdot 2 \mathrm{H}_{2} \mathrm{O}\right)$ (Merck, catalog number: 6521 )

25. Zinc sulfate heptahydrate $\left(\mathrm{ZnSO}_{4} \cdot 7 \mathrm{H}_{2} \mathrm{O}\right)$ (Merck, catalog number: 8883)

26. Cobalt nitrate hexahydrate $\left(\mathrm{Co}\left(\mathrm{NO}_{3}\right)_{2} \cdot 6 \mathrm{H}_{2} \mathrm{O}\right)$ (AppliChem, catalog number: 131258)

27. Copper (II) sulfate pentahydrate ( $\left.\mathrm{CuSO}_{4} \cdot 5 \mathrm{H}_{2} \mathrm{O}\right)(\mathrm{EMD}$ Millipore, catalog number: 102790)

28. Tris ultrapure (Duchefa Biochemie, catalog number: T1501)

29. Ammonium chloride $\left(\mathrm{NH}_{4} \mathrm{Cl}\right)$ (EMD Millipore, catalog number: 101145)

30. Magnesium acetate (Sigma-Aldrich, catalog number: M5661)

31. $\beta$-mercaptoethanol (EMD Millipore, catalog number: 805740)

32. Glycerol (AppliChem, catalog number: 131339)

33. Liquid nitrogen

34. Trichloracetic acid (TCA) (EMD Millipore, catalog number: 100807) (only for Western)

35. Acetone (EMD Millipore, catalog number: 100014) (only for Western)

36. Ammonium chloride (EMD Millipore, catalog number: 101145)

37. Sucrose (Sigma-Aldrich, catalog number: S0389)

38. Hydrochloric acid fuming 47\% (EMD Millipore, catalog number: 100317)

39. Methanol extra pure (Scharlau, catalog number: ME0301005P)

40. Bovine serum albumin (BSA) (Sigma-Aldrich, catalog number: A4503)

41. Protein assay dye reagent concentrate (Bio-Rad Laboratories, catalog number: 5000006)

42. BG11 growth medium (see Recipes)

43. Extraction buffer (see Recipes)

44. Sucrose buffer 1 (see Recipes)

45. Sucrose buffer 2 (see Recipes) 
46. $60 \%(w / v)$ sucrose (see Recipes)

47. $100 \%(w / v)$ TCA solution (see Recipes)

48. $80 \%(v / v)$ glycerol (see Recipes)

\section{Equipment}

1. Fluorescent lamps

2. Erlenmeyer flask $250 \mathrm{ml}$ (Duran Group, catalog number: 21771 36)

3. Flasks and magnetic stirrer for preparation of solutions

4. Orbital shaker (IKA, model: KS501)

5. Roux culture bottle $1 \mathrm{~L}$ (Sigma-Aldrich, catalog number: CLS12901L)

6. Glass bottles $5 \mathrm{~L}$ (Iso bottle blue cap 5,000 ml) (Kavalierglass, Simax, catalog number: CFB020)

7. Balances (Sartorius, catalog number: TE1502S and Precisa, model: XT120A)

8. pH meter (HACH LANGE SPAIN, CRISON, model: BASIC 20)

9. Flow meters (ABB, model: A6200)

10. Compressed air pump

11. Centrifuge (Beckman Coulter, model: Avanti J-25)

12. Rigid polypropylene tube (Fisher Scientific, catalog number: 11723904)

13. Fixed angle rotor (Beckman Coulter, model: JLA-16.250, catalog number: 363934)

14. Centrifuge bottles polypropylene $250 \mathrm{ml}$ (Beckman Coulter, catalog number: 356011)

15. Porcelain mortar and pestle $(10 \mathrm{~cm} \varnothing)$ (Fisher Scientific, catalog number: S337621)

16. Sterilization oven (JP SELECTA, catalog number: 2000381)

17. Autoclave (SANYO Labo Autoclave) (Panasonic Biomedical, model: MLS-3020U)

18. Automatic micropipettes

19. Vortex Mixer (Heidolph Instruments, model: Heidolph Reax 2000)

20. UV-VIS spectrophotometer (Thermo Electron, model: BioMate 5)

21. Fixed angle rotor (Beckman Coulter, model: JA-25.15)

22. Gradient maker (Hoefer, catalog number: SG15)

23. Peristaltic pump (Pharmacia Biotech, model: Pump P-1)

24. Magnetic plate stirrer (Cole-Parmer, catalog number: EW-04807-45)

25. Ultracentrifuge (Beckman Coulter, model: XL-80)

26. Swinging-bucket rotor (Beckman Coulter, model: SW $41 \mathrm{Ti}$ )

27. ISCO UA-6 detector UV/VIS (Density Gradient Fractionator, Teledyne Isco, catalog number: 679000-176) with TRIS ${ }^{\mathrm{TM}}$ pump (Teledyne Isco)

28. Microcentrifuge (Eppendorf, model: $5424 / 5415$ R)

29. Thermoblock (Eppendorf Thermomixer compact) (only for Western)

30. Metal connectors (Parker-Legris, catalog number: 018004 00)

31. $\mathrm{CO}_{2}$ cylinder containers 


\section{Procedure}

An overview of the whole protocol, divided in four steps, is shown in Figure 1.
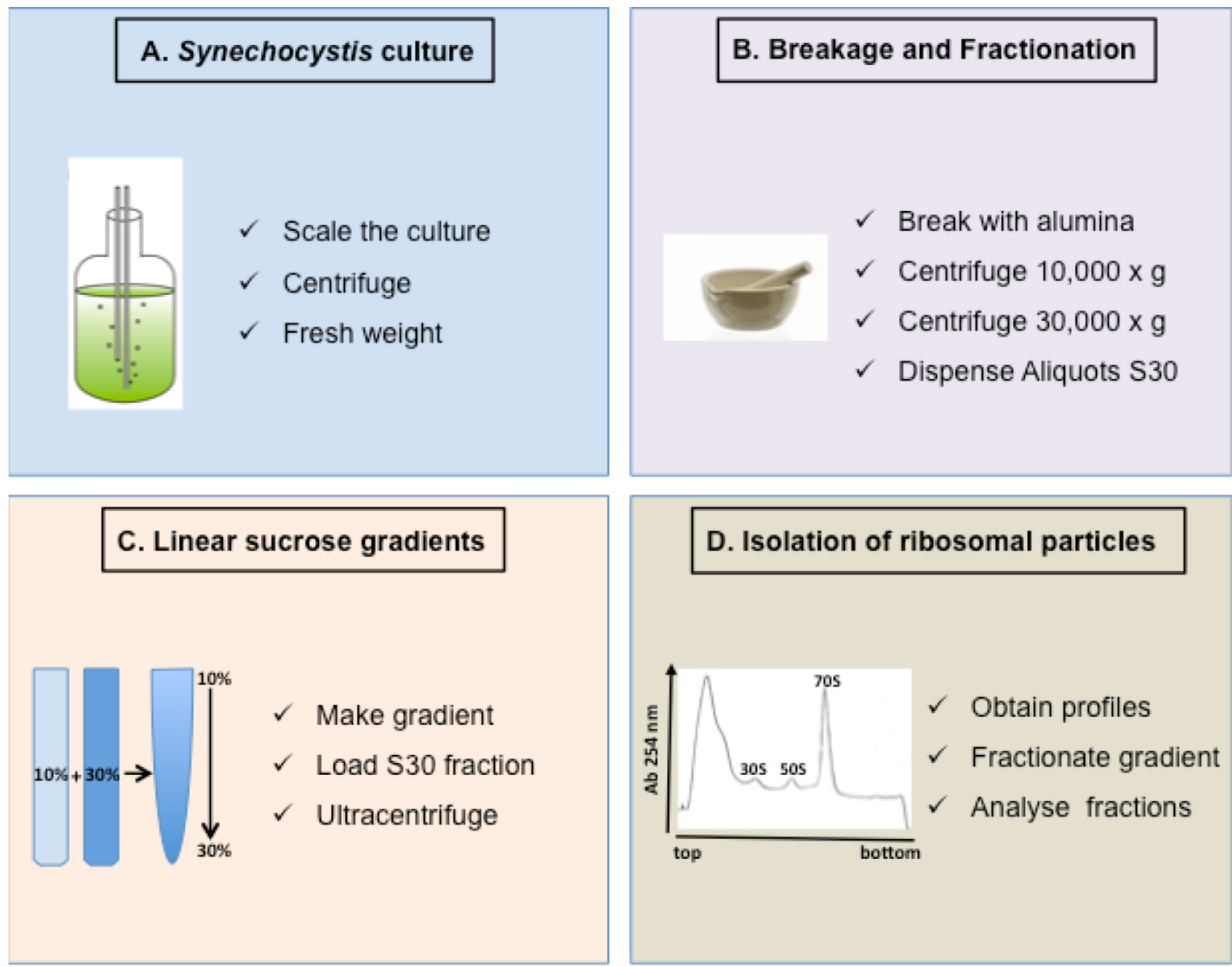

Figure 1. Scheme of the complete procedure described in the protocol

A. Cultivation of Synechocystis

1. Grow Synechocystis cells photoautotrophically at $30^{\circ} \mathrm{C}$ in BG11 medium (Rippka et al., 1979) supplemented with $1 \mathrm{~g} \mathrm{~L}^{-1}$ of $\mathrm{NaHCO}_{3}$ (BG11C) under continuous illumination (50 $\mu \mathrm{mol}$ of photons $\mathrm{m}^{-2} \mathrm{sec}^{-1}$, white light from fluorescent lamps).

a. Usually cultivation begins with a pre-inoculum $(50 \mathrm{ml})$ growing in Erlenmeyer flasks covered with cotton and placed on an orbital shaker (100 rpm) located in an illuminated room.

b. These cells are then used to inoculate around $750 \mathrm{ml}$ of BG11C medium in a Roux flask. Finally the culture is scaled to a $5 \mathrm{~L}$ bottle (without the cap and covered with cotton). Note: To achieve optimal growth, the cultures in Roux flasks and in $5 L$ bottles are bubbled with $\mathrm{CO}_{2}$-enriched air $(1 \% \mathrm{~V} / \mathrm{V})$, using a rigid polypropylene tube, silicone tubing and metal connectors. A compressed air stream drives bubbling and the air- $\mathrm{CO}_{2}$ mixture is established using flow meters.

2. Estimation of growth phase 
A volume of 3-5 $\mathrm{L}$ of cells, in exponential or stationary growth phase depending on the purpose of each experiment, is used. Growth phase is estimated by measuring total chlorophyll content in methanolic extracts of cells (McKinney, 1941).

a. Centrifuge $1 \mathrm{ml}$ of culture in a $1.5 \mathrm{ml}$ microcentrifuge tube at $12,000 \times \mathrm{g}$.

b. Discard $950 \mu \mathrm{l}$ of the supernatant and resuspend the pellet in the remaining $50 \mu \mathrm{l}$. Add 950 $\mu \mathrm{l}$ of methanol and vortex vigorously for $1 \mathrm{~min}$.

c. Centrifuge at $12,000 \times g$ for 2 min. Chlorophyll concentration is calculated by measuring absorbance at $665 \mathrm{~nm}$ in the supernatant $\left(E=74.46 \mathrm{ng}^{-1} \mathrm{ml} \mathrm{cm}^{-1}\right)$.

d. Cultures with $2-4 \mu \mathrm{g} / \mathrm{ml}$ of total chlorophyll are considered to be in exponential phase and cultures with more than $5 \mu \mathrm{g} / \mathrm{ml}$ are considered stationary.

3. Harvest cells

a. Centrifuge at 9,605 $\mathrm{xg}$ in a JLA-16.250 Beckman rotor, for $10 \mathrm{~min}$ at $4{ }^{\circ} \mathrm{C}$.

b. Combine the cells in a single bottle and estimate fresh weight. $2-5 \mathrm{~g}$ of cells are enough for the procedure.

B. Breakage and fractionation of Synechocystis cells

1. Pre-treatment

All glass materials, porcelain mortar and pestle were heated in a sterilization oven at $200^{\circ} \mathrm{C}$ for $3 \mathrm{~h}$ and all plastic materials were autoclaved at $121{ }^{\circ} \mathrm{C}$ for $20 \mathrm{~min}$.

Note: RNase-free water was used to prepare all buffers.

2. Breakage of Synechocystis cells

Place in a pre-chilled porcelain mortar the same weight of cells and alumina. Put the mortar on top of an ice bucket with ice. Mix with the pestle and once the cells and the alumina are well mixed continue grinding for $2 \mathrm{~min}$. Add around $20 \mathrm{ml}$ extraction buffer (1 or $10 \mathrm{mM} \mathrm{Mg}$-acetate) with $\beta$-mercaptoethanol added immediately before use.

3. Fractionation of Synechocystis cells

Recover as much material as possible in two polypropylene tubes of $15 \mathrm{ml}$. Centrifuge at 10,000 $x \mathrm{~g}$ for $10 \mathrm{~min}$ in a JA-25.15 rotor at $4{ }^{\circ} \mathrm{C}$ to eliminate the alumina, the cell debris and the unbroken cells. Transfer the supernatant into new $15 \mathrm{ml}$ tubes and centrifuge at 30,000 $\mathrm{xg}$ for $30 \mathrm{~min}$ in the same rotor at $4{ }^{\circ} \mathrm{C}$. This centrifugation is required to completely eliminate membranes.

4. Freezing reserve

Dispense aliquots from the supernatant of this centrifugation step (S30 fraction) in $1.5 \mathrm{ml}$ Eppendorf tubes with 5\% (v/v) glycerol. For this process, place the $1.5 \mathrm{ml}$ tubes on ice and add $40 \mu \mathrm{l}$ of $80 \%(\mathrm{v} / \mathrm{v})$ glycerol and $600 \mu \mathrm{l}$ of the S30 fraction to each tube. Mix gently, using a micropipette, and rapidly freeze the tubes in liquid nitrogen. Before freezing reserve an aliquot to determine the total protein amount of this $\mathbf{S} 30$ fraction by the standard method of Bradford, using albumin bovine as reference (Bradford et al., 1976). Usually 10-15 $\mu \mathrm{g} / \mu \mathrm{l}$ of total protein concentration is obtained in S30 fraction. 
Notes:

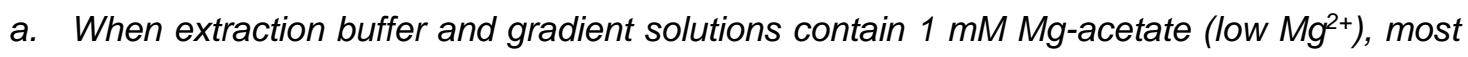
bacterial ribosomes are dissociated into $30 \mathrm{~S}$ and 50 S subunits but when using $10 \mathrm{mM} \mathrm{Mg}$ acetate (high $\mathrm{Mg}^{2+}$ ), in the buffers and solutions, the $70 \mathrm{~S}$ vacant ribosome peak is mainly observed.

b. It is worth noting that in cyanobacteria, phycobiliproteins represent around $30 \%$ of total protein concentration. This fact must be taken into account when considering the amount of the S30 fraction needed for the next step of this procedure.

c. The S30 fraction can be stored as different aliquots at $-80^{\circ} \mathrm{C}$ to load separate gradients on different days. This is a backup in case there is any problem in later steps of the protocol, especially in the centrifugation, fractionation or generation of the gradient profiles.

C. Preparation of sucrose gradients and ultracentrifugation

1. Preparation of sucrose gradients

a. Prepare a $10-30 \%$ sucrose gradient using a linear gradient maker connected to a peristaltic pump (P1) working at $120 \mathrm{ml} / \mathrm{h}$. Use sucrose buffer 1 and 2 solutions (either with 1 or 10

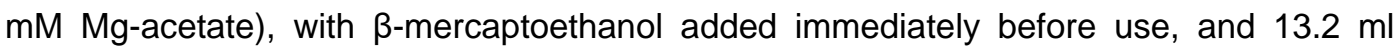
ultracentrifuge thin-wall polyallomer tubes. Place the gradient maker on top of a magnetic stirrer plate.

b. Introduce a small magnetic stir bar in the gradient maker compartment connected to the pump. Pour $5.6 \mathrm{ml}$ of sucrose buffer 1 in this compartment and $5.6 \mathrm{ml}$ of sucrose buffer 2 in the other compartment of the gradient maker. The outlet of the peristaltic pump is connected to a glass capillary that is introduced into the gradient tube.

c. Connect the two compartments of the gradient maker and simultaneously turn on pump P1.

d. Stop the pump when the solutions introduced in the gradient maker are exhausted, before air bubbles enter the gradient.

e. Then remove the capillary from the gradient tube slowly so as not to disturb it.

f. Tubes are stored at $4{ }^{\circ} \mathrm{C}$ for about $8 \mathrm{~h}$ before use to allow equilibration of the linear sucrose gradients.

g. Before loading, filter the $\mathrm{S} 30$ fraction through a $0.45 \mu \mathrm{m}$ filter unit.

2. Ultracentrifugation

a. Gently layer the S30 fraction (100-300 $\mu \mathrm{l})$ on top of the 10-30\% sucrose gradient using a micropipette and via single drops close to the surface of the sucrose gradient.

b. Centrifuge at $77,175 \times g$, for $8 \mathrm{~h}$ at $2{ }^{\circ} \mathrm{C}$ in a pre-cooled Beckman ultracentrifuge in the SW 41 Ti rotor.

D. Isolation of ribosomal particles

1. Carefully remove the gradient tubes from the centrifuge and completely fill each tube with Milli$\mathrm{Q}$ water before placing it in the ISCO fractionation system. 
2. Fractionate the gradient from the top using $60 \%(\mathrm{w} / \mathrm{v})$ sucrose to push the content of the tube toward the UV detector $\left(\mathrm{A}_{254}\right)$, with the TRIS ${ }^{\mathrm{TM}}$ pump (flow rate $1 \mathrm{ml} / \mathrm{min}$ ). Turn on the recorder $(1 \mathrm{~cm} / \mathrm{min}$, sensitivity 1$)$ to obtain the sucrose gradient profile while the fractions $(0.5 \mathrm{ml})$ are manually collected.

3. Place the fractions in a container with liquid nitrogen, as they are collected, to freeze them quickly and then store at $-80^{\circ} \mathrm{C}$ until use.

Representative examples of the expected profiles are shown in Figure 2.

A

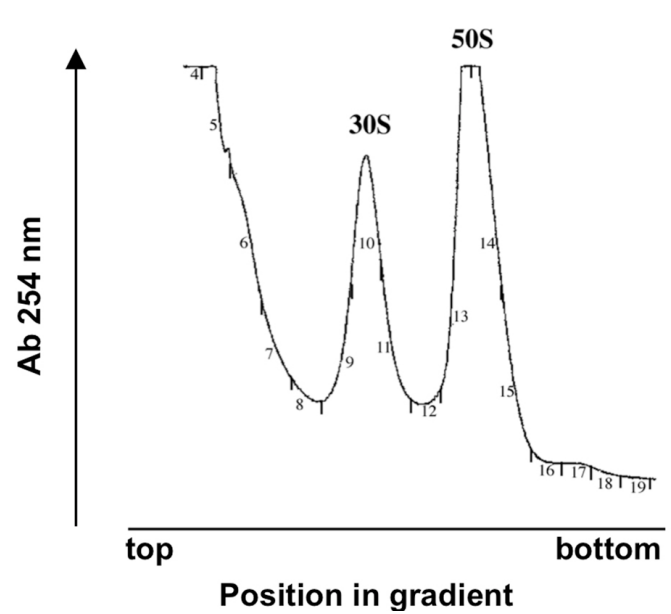

B

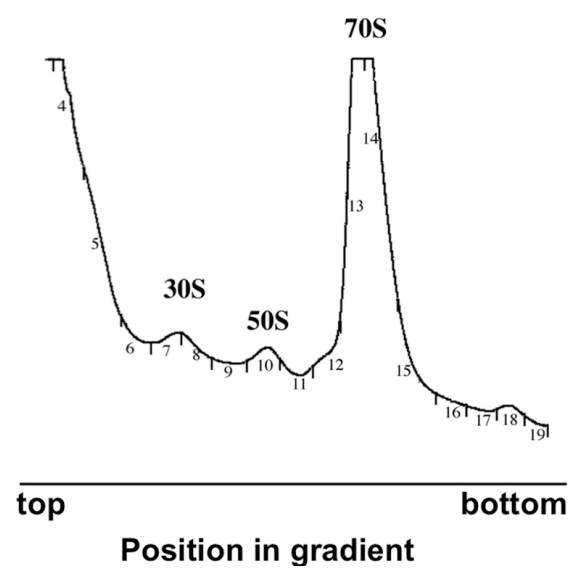

Figure 2. Sedimentation profiles showing the free subunits and $70 \mathrm{~S}$ vacant ribosomes. The Synechocystis S30 supernatant was fractionated on a 10-30\% sucrose density gradient in the presence of $1 \mathrm{mM}(\mathrm{A})$ or $10 \mathrm{mM}(\mathrm{B}) \mathrm{Mg}^{2+}$. Small numbers refer to collected fractions. Adapted from (Galmozzi et al., 2016).

4. The treatment of the fractions from this point depends on the use that will be given to them. In the case of analysis by Western blot, precipitate the total protein with 100\% (w/v) TCA (see Recipes).

a. Add $55 \mu \mathrm{l}$ of this solution to each fraction (10\% TCA final concentration), incubate on ice for $30 \mathrm{~min}$ and centrifuge in a microcentrifuge (Eppendorf $5415 \mathrm{R}$ ) at maximal speed and $4{ }^{\circ} \mathrm{C}$ for $10 \mathrm{~min}$.

b. Discard the supernatant and add $1 \mathrm{ml}$ of $-20^{\circ} \mathrm{C}$ chilled acetone to each fraction pellet to eliminate residual TCA.

c. Remove the acetone carefully as not to affect the integrity of the pellet.

d. Dry the pellets through evaporation of acetone by incubating the tubes at $60{ }^{\circ} \mathrm{C}$ in a thermoblock.

e. Resuspend the pellets in RNase-free Milli-Q water and add loading buffer for standard electrophoresis protocols. 


\section{Notes}

Nowadays the analog signal from the ISCO UA-6 detector can be transformed into a digital signal using a Bus-Powered Multifunction DAQ USB Device (NI USB-6008) from National Instruments.

\section{Recipes}

1. BG11 growth medium (Rippka et al., 1979)

a. $\mathrm{BG} 11 \mathrm{C}(1 \mathrm{~L})$

$1.5 \mathrm{~g} \mathrm{NaNO}_{3}$

$1 \mathrm{~g} \mathrm{NaHCO}_{3}$

$0.2 \mathrm{ml}_{1} \mathrm{M} \mathrm{K}_{2} \mathrm{HPO}_{4}$

$10 \mathrm{ml}$ concentrate BG11 (see below)

Autoclave at $121{ }^{\circ} \mathrm{C}, 1 \mathrm{~atm}$ for $20 \mathrm{~min}$

b. Concentrate BG11

$7.5 \mathrm{~g} / \mathrm{L} \mathrm{MgSO} 4 \cdot 7 \mathrm{H}_{2} \mathrm{O}$

$0.6 \mathrm{~g} / \mathrm{L}$ citric acid

$0.1 \mathrm{~g} / \mathrm{L}$ EDTA-Na2

$100 \mathrm{ml} \mathrm{A}_{5}$ solution (see below)

$3.6 \mathrm{~g} / \mathrm{L} \mathrm{CaCl} 2 \cdot 2 \mathrm{H}_{2} \mathrm{O}$

$0.6 \mathrm{~g} / \mathrm{L}$ citrate $\mathrm{Fe}-\mathrm{NH}_{4}$

$2 \mathrm{~g} / \mathrm{L} \mathrm{Na}_{2} \mathrm{CO}_{3}$

c. $A_{5}$ solution

$2.86 \mathrm{~g} / \mathrm{L} \mathrm{H}_{3} \mathrm{BO}_{3}$

$1.81 \mathrm{~g} / \mathrm{L} \mathrm{MnCl} 2 \cdot 4 \mathrm{H}_{2} \mathrm{O}$

$0.31 \mathrm{~g} / \mathrm{L} \mathrm{Na} 2-\mathrm{MoO}_{4} \cdot 2 \mathrm{H}_{2} \mathrm{O}$

$0.22 \mathrm{~g} / \mathrm{L} \mathrm{ZnSO}{ }_{4} \cdot 7 \mathrm{H}_{2} \mathrm{O}$

$0.05 \mathrm{~g} / \mathrm{L} \mathrm{Co}\left(\mathrm{NO}_{3}\right) \cdot 6 \mathrm{H}_{2} \mathrm{O}$

$0.08 \mathrm{~g} / \mathrm{L} \mathrm{CuSO}_{4} \cdot 5 \mathrm{H}_{2} \mathrm{O}$

2. Extraction buffer

$20 \mathrm{mM}$ Tris- $\mathrm{HCl}, \mathrm{pH} 8.0$

1 or $10 \mathrm{mM} \mathrm{Mg}$-acetate

$20 \mathrm{mM} \mathrm{NH}_{4} \mathrm{Cl}$

$5 \mathrm{mM} \beta$-mercaptoethanol (added just prior to use)

This solution (lacking the $\beta$-mercaptoethanol) was autoclaved at $121^{\circ} \mathrm{C}, 1 \mathrm{~atm}$ for $20 \mathrm{~min}$

3. Sucrose buffer 1

$20 \mathrm{mM}$ Tris- $\mathrm{HCl}, \mathrm{pH} 8.0$

1 or $10 \mathrm{mM} \mathrm{Mg-acetate}$

$20 \mathrm{mM} \mathrm{NH}_{4} \mathrm{Cl}$ 
$10 \%(\mathrm{w} / \mathrm{v})$ sucrose

$5 \mathrm{mM} \beta$-mercaptoethanol (added just before use)

4. Sucrose buffer 2

$20 \mathrm{mM}$ Tris- $\mathrm{HCl}, \mathrm{pH} 8.0$

1 or $10 \mathrm{mM}$ Mg-acetate

$20 \mathrm{mM} \mathrm{NH}_{4} \mathrm{Cl}$

$30 \%(w / v)$ sucrose

$5 \mathrm{mM} \beta$-mercaptoethanol (added just before use)

Sucrose buffer 1 and 2 are prepared from autoclaved RNase free stocks and sucrose was dissolved at the end

5. $60 \%(w / v)$ sucrose

Prepared with Milli-Q water and heating. Once the sucrose is dissolved the volume is adjusted with a test tube

6. $100 \%(w / v)$ TCA solution

To a previously unopened bottle containing $500 \mathrm{~g}$ of TCA, add $227 \mathrm{ml}$ of sterile Milli-Q water.

The resulting solution will contain $100 \%$ (w/v) TCA

7. $80 \%(v / v)$ glycerol

Prepared with Milli-Q water and autoclaved at $121^{\circ} \mathrm{C}, 1 \mathrm{~atm}$ for $20 \mathrm{~min}$ Note: All solutions are stored at $4^{\circ} \mathrm{C}$.

\section{Acknowledgments}

This protocol was adapted and modified from previously published studies by Sugita et al. (2000). We are grateful to Dr. J. de la Cruz for his expert advice, helpful discussions and a critical reading of the manuscript. We thank M. Roldán for technical assistance. This work was supported by Junta de Andalucía (grant P07-CVI-02792 and group BIO-284) and Spanish Ministerio de Economía y Competitividad (MINECO) and Fondo Social Europeo (FSE) (grant BFU2013-41712-P).

\section{$\underline{\text { References }}$}

1. Bradford, M. M. (1976). A rapid and sensitive method for the quantitation of microgram quantities of protein utilizing the principle of protein-dye binding. Anal Biochem 72: 248-254.

2. Galmozzi, C. V., Florencio, F. J. and Muro-Pastor, M. I. (2016). The cyanobacterial ribosomalassociated protein LrtA is involved in post-stress survival in Synechocystis sp. PCC 6803. PLoS One 11(7): e0159346.

3. McKinney, G. (1941). Absorption of light by chlorophyll solution. J Biol Chem 140:315-21.

4. Mutsuda, M. and Sugiura, M. (2006). Translation initiation of cyanobacterial rbcS mRNAs requires the 38-kDa ribosomal protein S1 but not the Shine-Dalgarno sequence: development of a cyanobacterial in vitro translation system. J Biol Chem 281(50): 38314-38321. 
5. Rippka, R., Deruelles, J., Waterbury, J. B., Herdman, M. and Stanier, R. Y. (1979). Generic assignments, strain histories and properties of pure cultures of cyanobacteria. $\mathrm{J}$ Gen Microbiol 111: 1-61.

6. Sato, N., Wada, A. and Tanaka, A. (1998). Ribosomal proteins in the cyanobacterium Anabaena variabilis strain M3: presence of L25 protein. Plant Cell Physiol 39(12): 1367-1371.

7. Sugita, C., Sugiura, M. and Sugita, M. (2000). A novel nucleic acid-binding protein in the cyanobacterium Synechococcus sp. PCC6301: a soluble 33-kDa polypeptide with high sequence similarity to ribosomal protein S1. Mol Gen Genet 263(4): 655-663. 